\title{
Characterization and Thermal Behavior Study of Biomass from Invasive Acacia mangium Species in Brunei Preceding Thermochemical Conversion
}

\author{
Ashfaq Ahmed 1,2,3 ${ }^{\mathbb{D}}$, Muhammad S. Abu Bakar ${ }^{2} \mathbb{D}$, Abdul Razzaq ${ }^{3}$, Syarif Hidayat ${ }^{2} \mathbb{D}$, Farrukh Jamil $^{3}$, \\ Muhammad Nadeem Amin ${ }^{4}$, Rahayu S. Sukri ${ }^{5}$, Noor S. Shah ${ }^{6}$ and Young-Kwon Park ${ }^{1, *}$
}

\section{check for}

updates

Citation: Ahmed, A.; Bakar, M.S.A.; Razzaq, A.; Hidayat, S.; Jamil, F.; Amin, M.N.; Sukri, R.S.; Shah, N.S.; Park, Y.-K. Characterization and Thermal Behavior Study of Biomass from Invasive Acacia mangium Species in Brunei Preceding Thermochemical Conversion. Sustainability 2021, 13, 5249. https://doi.org/10.3390/ su13095249

Academic Editor:

Alberto-Jesus Perea-Moreno

Received: 7 April 2021

Accepted: 3 May 2021

Published: 7 May 2021

Publisher's Note: MDPI stays neutral with regard to jurisdictional claims in published maps and institutional affiliations.

Copyright: (c) 2021 by the authors Licensee MDPI, Basel, Switzerland. This article is an open access article distributed under the terms and conditions of the Creative Commons Attribution (CC BY) license (https:// creativecommons.org/licenses/by/ $4.0 /)$
1 School of Environmental Engineering, University of Seoul, Seoul 02504, Korea; ashfaqengr97@gmail.com

2 Faculty of Integrated Technologies, Universiti Brunei Darussalam, Jalan Tungku Link BE1410, Brunei; saifullah.bakar@ubd.edu.bn (M.S.A.B.); hidayat231984@gmail.com (S.H.)

3 Department of Chemical Engineering, COMSATS University Islamabad, Raiwind Road, Lahore 54000, Pakistan; abdulrazzaq@cuilahore.edu.pk (A.R.); fjamil@cuilahore.edu.pk (F.J.)

4 Department of Chemical Engineering, NFC-Institute of Engineering and Technology, Multan 60000, Pakistan; nadeem727@hotmail.com

5 Institute for Biodiversity and Environmental Research, Universiti Brunei Darussalam, Jalan Tungku Link BE 1410, Brunei; rahayu.sukri@ubd.edu.bn

6 Department of Environmental Sciences, COMSATS University Islamabad, Vehari 61100, Pakistan; samadchemistry@gmail.com

* Correspondence: catalica@uos.ac.kr

Abstract: Acacia mangium is a widely grown tree species across the forests in Brunei Darussalam, posing a threat to the existence of some native species in Brunei Darussalam. These species produce large quantities of lignocellulosic biomass from the tree parts comprising the phyllodes, trunk, bark, twigs, pods, and branches. This study examined the thermochemical characteristics and pyrolytic conversion behavior of these tree parts to assess the possibility of valorization to yield bioenergy. Proximate, ultimate, heating value, and Fourier Transform Infrared Spectroscopy (FTIR) analyses were performed to assess the thermochemical characterization, while thermogravimetric analysis was conducted to examine the pyrolytic degradation behavior. Proximate analysis revealed a moisture content, volatile, fixed carbon, and ash contents of 7.88-11.65 wt.\%, 69.82-74.85 wt.\%, 14.47-18.31 wt.\%, and 1.41-2.69 wt.\%, respectively. The heating values of the samples were reported in a range of $19.51-21.58 \mathrm{MJ} / \mathrm{kg}$ on a dry moisture basis, with a carbon content in the range of 45.50-50.65 wt.\%. The FTIR analysis confirmed the heterogeneous nature of the biomass samples with the presence of multiple functional groups. The pyrolytic thermal degradation of the samples occurred in three major stages from the removal of moisture and light extractives, hemicellulose and cellulose decomposition, and lignin decomposition. The bio-oil yield potential from the biomass samples was reported in the range of 40 to $58 \mathrm{wt} . \%$, highlighting the potential of Acacia mangium biomass for the pyrolysis process.

Keywords: Acacia mangium; Brunei Darussalam; invasive species; biomass characterization; thermogravimetric analysis

\section{Introduction}

The search for substitute energy resources is growing as fossil fuel resources are rapidly diminishing, and the awareness of environmental pollution is increasing [1-3]. Energy is one of the most vital commodities of present life, with its demand growing constantly. The vast majority of the energy requirements are being met through fossil fuels. The interest in finding alternative energy resources is increasing as emphasis has been placed on energy recovery from solar, tidal, wind, and biomass resources [4-7]. These resources are renewable and sustainable, but the energy density and economic recovery of 
energy from these sources are the real challenges [8]. Biomass is an abundant renewable energy resource available globally with benefits over other resources because the pyrolytic transformation of biomass produces biofuels in solid, liquid, and gaseous states $[9,10]$. Pyrolysis is a thermochemical conversion technique wherein biomass feedstock is heated at high temperatures in an oxygen-free environment. The properties of pyrolysis yields are influenced greatly by the properties of the biomass and the process parameters maintained through the conversion of biomass. Therefore, comprehensive knowledge of the physicochemical properties and the thermal degradation behavior of the feedstock is a prerequisite to the valorization of biomass $[11,12]$.

Acacia mangium (AM) are exotic tree species introduced to Brunei Darussalam in the early 1990s for forestry plantations and to provide timber for the furniture industry $[13,14]$. $\mathrm{AM}$ is indigenous to Australia and is categorized as a fast-growing species. This species has been recognized as invasive and is posing threats to the biodiversity of Brunei by endangering some local species, such as Karangas, in the country, which are on the edge of depletion and has negative impacts on the soil properties [15-17]. AM species are abundantly available throughout the forests of Brunei, and vast amounts of biomass can be harvested from its tree parts to offer sustainable feedstock to produce biofuels in the country. Brunei is heavily reliant on fossil resources to meet its energy requirements and committed to shift a major share of energy production from fossils to renewable resources under the country's policy document "Vision Brunei 2035" [14].

The thermochemical characteristics study of the biomass is a widely practiced prerequisite prior to its valorization as it provides first-hand information regarding the energy potential, viability of feedstock, process parameters design, and environmental sustainability [18-20]. Griffin et al. reported the global aspects of using Australian acacias for multiple applications including pulp and paper, soil applications, solid wood products, and fuel applications and the anticipated future trends [21]. Chemetova et al., reported the characterization of mature and juvenile plant tissues for the sustainable valorization of biomass from Acacia melanoxylon [21] while Ferreira et al. reported on the potential of Acacia dealbata as a raw material to produce bioethanol [21]. Titiloye et al. presented a study on the thermochemical characterization of the agricultural residues in West Africa to produce bioenergy [22]. Hernandez et al. employed the thermochemical characterization study to report the feasibility of biofuel production from waste banana peduncle [23] while Singh et al. reported on the widespread characterization via the application of proximate analysis, ultimate analysis, and compositional analysis of various indigenous lignocellulosic biomasses to assess the bioenergy production potential [24]. Kan et al. reviewed the influence of the properties of biomass and process parameters on the properties of the pyrolysis products to show the significance of thermochemical characterization studies [25]. Furthermore, several other studies by Garcia et al. [26], Odetoye et al. [27], Abdullah et al. [28], and Naik et al. [29] have also reported on the biofuel characteristics of several types of biomass for potential valorization via thermochemical conversion routes.

In line with the efforts of the Brunei government, this study aimed at the evaluation of the suitability and potential of AM biomass to harvest bioenergy via the application of thermochemical routes especially the pyrolysis process. To the best of the authors knowledge, there are no reports on assessing the thermochemical characterization and pyrolytic conversion behavior of individual tree parts of AM trees in Brunei Darussalam. This study is expected to provide a useful dataset for the beneficial management of biomass from AM species in Brunei Darussalam via a thermochemical conversion route particularly for the application of the pyrolysis process to produce bio-oil and biochar for bioenergy and other value-added applications.

\section{Materials and Methods}

The samples were collected from the AM trees growing in the forest within the premises of Gadong, Brunei Darussalam, including the biomass from phyllodes, trunk, bark, twigs, pods, and branches. The samples were dried under ambient atmospheric conditions 
for 10 days and then crushed using the ASTM E 1757-01. The crushed biomass was sieved through the 60 mesh sieve to retain the uniform particle size. The samples were carefully packed in plastic bags to avoid cross mixing and contamination. Proximate analysis, ultimate analysis, and heating value analysis were performed to study the thermochemical characterization of the biomass samples. The moisture content in the biomass samples was determined according to the ASTM E871-82 procedure while the volatile matter and ash content were determined following the ASTM method D3175-07 and ASTM method D3174-04, respectively. The fixed carbon content in the biomass samples was determined by calculating the difference of moisture, volatile, and ash content from 100 . The ultimate analysis of the biomass samples was performed to determine the carbon, hydrogen, nitrogen, and sulfur content in the samples using a CHNS Analyzer (model Flash EA 1112 Series) from CE Instruments, Thermo-Quest, Italy. The oxygen content was determined by calculating the difference using Equation (1).

$$
\text { Oxygen content }(w t . \%)=100-(C+H+N+S)
$$

The heating values of the samples were determined using a model C-200 calorimeter (P.A. Hilton Ltd. United Kingdom) following the procedure given in ASTM D 5468-02. The FTIR analysis was performed using an FTIR spectroscopic analyzer from Perkin Elmer. The spectra were recorded at the scan rate of 8 at the step size of $1 \mathrm{~cm}^{-1}$ in the 600 to $4000 \mathrm{~cm}^{-1}$ range. Further detailed procedures and equations about the proximate analysis, ultimate analysis, and heating value analysis are provided as Supplementary Data. The pyrolytic degradation behavior of the biomass samples was studied by means of thermogravimetric analysis (TGA and DTG) in the range of $50{ }^{\circ} \mathrm{C}$ to $900{ }^{\circ} \mathrm{C}$ at a heating rate of $25^{\circ} \mathrm{C} / \mathrm{min}$ under a constant supply of $99.99 \%$ nitrogen using a thermogravimetric analyzer, model TGA-7, Perkin Elmer, United States of America (USA). A precisely measured quantity (5 g) of each sample was used to heat under pyrolysis conditions in the heating chamber of the thermogravimetric analyzer to evaluate the biomass decomposition patterns and study the pyrolytic degradation behavior.

\section{Results and Discussion}

\subsection{Proximate Analysis}

Table 1 lists the proximate analysis of the AM biomass samples. Proximate analysis is important for determining the potential and suitability of biomass and provides the information about the moisture, volatile matter, fixed carbon and ash contents. The moisture content in biomass plays a vital role in selecting an appropriate conversion process and has a significant effect on the properties of biofuels produced from pyrolysis especially bio-oil in terms of its heating value, viscosity, stability, homogeneity, and density [30]. A higher amount of moisture in biomass reduces the heating temperature in the reactor during the thermochemical processes because they involve endothermic reactions that can disturb the overall energy balance of the process [31,32].

The moisture content also affects the storage, handling, and transport of biomass feedstock. Generally, moisture content of less than $15 \%$ in biomass is preferred for the conversion via pyrolysis process [33]. The moisture in the AM biomass was reported to be in the range of 7.88 to $11.65 \mathrm{wt} . \%$, with the lowest value reported in the pods and the highest value reported in the trunk which showed a good perspective for the use of this biomass as the feedstock of the pyrolysis process to produce bio-oil more efficiently $[34,35]$. Charusiri reported the moisture contents in paper mill residue biomass of $6.07 \%$, which was lower than that reported in the phyllodes, bark, trunk twigs, and branches but comparable to pods biomass [36]. Marsoem and Irawati reported a moisture content of $13.3 \%, 11.2 \%$, and $13.0 \%$ in the bottom, middle, and top tree parts of the black wattle (Acacia Auriculiformis), respectively, presenting comparable values to the trunk, twigs, and branch biomass reported in the present study [37]. Moreover, the moisture content in the AM biomass was comparable to other biomass studies from forest residues, woody biomass, and industrial waste assessed for bioenergy production reported [27,38,39]. 
Table 1. Proximate analysis and calorific values of the samples.

\begin{tabular}{cccccc}
\hline Sample & $\begin{array}{c}\text { MC } \\
\text { (wt.\%) }\end{array}$ & $\begin{array}{c}\text { VM } \\
\text { (wt.\%) }\end{array}$ & $\begin{array}{c}\text { FC } \\
\text { (wt. \%) }\end{array}$ & $\begin{array}{c}\text { Ash } \\
\text { (wt. } \%)\end{array}$ & $\begin{array}{c}\text { HHV } \\
\text { (MJ/kg) }\end{array}$ \\
\hline Phyllodes & $9.06 \pm 0.17$ & $70.52 \pm 0.45$ & $18.31 \pm 0.09$ & $2.11 \pm 0.16$ & 21.16 \\
\hline Trunk & $11.65 \pm 0.15$ & $69.82 \pm 0.39$ & $16.71 \pm 0.18$ & $1.82 \pm 0.19$ & 19.51 \\
\hline Bark & $9.78 \pm 0.09$ & $73.35 \pm 0.29$ & $15.45 \pm 0.10$ & $1.42 \pm 0.18$ & 21.50 \\
\hline Twigs & $10.29 \pm 0.12$ & $74.85 \pm 0.56$ & $14.47 \pm 0.10$ & $1.41 \pm 0.14$ & 20.87 \\
\hline Pods & $7.88 \pm 0.11$ & $73.80 \pm 0.35$ & $15.63 \pm 0.13$ & $2.69 \pm 0.29$ & 21.58 \\
\hline Branches & $9.98 \pm 0.10$ & $72.39 \pm 0.19$ & $15.38 \pm 0.10$ & $2.25 \pm 0.20$ & 21.26 \\
\hline
\end{tabular}

MC: moisture contents, VM: volatile matter, FC: Fixed Carbon, HHV: Higher heating values.

Volatile matter is the fraction of biomass that transforms into vapors during the pyrolysis process and condense to produce bio-oil and non-condensable gaseous products. The vapors include mainly hydrocarbons, hydrogen, carbon monoxide, carbon dioxide, and tars present in the biomass. A higher fraction of the volatile matter in the biomass feedstock indicates its ease of conversion and disintegration through pyrolytic conversion [29]. Moreover, a feedstock with a greater volatile fraction tends to yield greater percentages of bio-oil [40]. On the other hand, the correlation between the volatile matter in biomass with the heating value is complicated because a higher percentage of volatile matter cannot ensure a superior heating value as some of the volatile matter constituents are non-combustible fractions, such as $\mathrm{CO}_{2}$ and $\mathrm{H}_{2} \mathrm{O}$ [41]. The volatile matter in AM biomass samples was reported in the range of 72.39-76.52 wt.\% with the lowest value reported in phyllodes biomass showing a higher tendency of phyllodes biomass to produce biochar among the samples from AM biomass. Whereas the highest fraction of the volatile matter was reported in the pod biomass indicating its tendency to produce higher yields of bio-oil among the samples. Usually, volatile matter content in biomass feedstocks is ranged between 60 to $85 \%$ and from this perspective the AM biomass was reported to have the better potential to produce bio-oil via pyrolysis process and syngas via gasification process $[19,42]$. Furthermore, the volatile matter in the AM was found to be higher than in the pine cone heart biomass (66\%), Cocoa beans husk (69\%), and Miscanthus (45\%) while it was found to be in good comparison with the Pine cone leaf biomass $(75.9 \%)$, Wheat straw (76\%) and Holm oak branch chips (75.9\%) [38] and other biomass and residues studied for energy conversion, such as leaf litter, paper mills residues, eucalyptus hybrid, and A. auriculiformis $[18,36,43]$.

Ash content in biomass is a non-combustible component comprising of inorganic minerals and is generally categorized into three groupings, including the water-soluble, soluble in organic solvents, and pure compounds [44]. The ash content significantly influences the quality of products formed during the thermochemical transformation. Its higher percentage in feedstock results in severe technical challenges, such as slag formation, product quality deterioration, corrosion problems, and increased processing costs [45]. Lower ash content is highly favorable for the biomass to use as a pyrolysis feedstock. The ash content in the AM biomass was in the lower range (1.41 to $2.69 \mathrm{wt} . \%)$, making it promising from a bioenergy perspective. The ash content in the AM biomass samples was lower than the values reported by Akhtar et al., 2015 for mango, ashoka and poplar leaf litter biomass, which were in the range of 3.70 to $9.46 \%$ [18]. A study on Acacia nilotica reported an ash content of 7.3\% [46]. Kumar et al., 2011 and Charusiri, 2015 reported an ash content of $0.30 \%$ and $9.32 \%$ in the biomass from A. auriculiformis and paper mills residues, respectively $[36,43]$. The differences in ash content among the different biomass feedstock in the literature and current study were attributed to the variations in the soil and environmental effects, which affect the ash content and properties of the biomass [19]. The feedstock with a high ash percentage usually entails the system of ash elimination before processing [47]. The highest and lowest ash percentage among the AM biomass samples 
was reported from the pods and twigs biomass, respectively. Besides, a small fraction of ash in biomass could impart a positive effect during pyrolysis processing by providing some catalytic activity for the improved conversion of biomass to products.

The fixed carbon content is the fraction of biomass that usually does not decompose during pyrolytic conversion and contributes to biochar production. The fixed carbon content in the AM samples was reported to be in the range of 14.47-18.31 wt.\%. The phyllodes biomass showed the highest fixed carbon content highlighting its potential for the higher yields of biochar, which was reconfirmed from the volatile matter content as well. The twigs biomass had the lowest fixed carbon content but the highest percentage of volatile matter, reconfirming its potential for producing higher yields of bio-oil from the pyrolysis process.

\subsection{Ultimate Analysis}

Table 2 lists the results of the ultimate analysis, and other relevant properties of AM biomass samples. This analysis is also of fundamental importance for biomass before its use in the conversion process. The carbon, hydrogen, and oxygen content are the most important contents regarding its fuel value. In contrast, the nitrogen and sulfur content are essential from an environmental emissions perspective. The carbon content in the AM biomass samples was reported in the range of 45.50-50.65 wt.\% with the highest and lowest value reported for the pods and trunk biomass, respectively. The carbon content in samples could be attributed to the relevant heating values of the biomass samples. Carbon, oxygen, and hydrogen are the principal elements present in the plant biomass as building blocks of the major constituents, including cellulose, hemicellulose, and lignin. They constitute approximately $90 \%$ of the total mass of the plants [48]. The content fractions of these elements in biomass are influenced by the growing conditions of the plants, and these constituents have significant effects on the pyrolytic behaviors of the biomass and the products produced [48]. A higher fraction of carbon and hydrogen content and a lower fraction of oxygen content in the biomass are preferred and result in the better properties of biofuels [49]. The hydrogen content in AM biomass was reported to be in a range of 5.26-6.01 wt.\% with the highest and lowest values reported in phyllodes and bark biomass, respectively. While oxygen content in the biomass was reported to be in the range of 43.11$48.27 \mathrm{wt} . \%$ with the lowest and highest values reported in the twigs and trunk biomass, respectively. The highest percentage of carbon content in the pods biomass resulted in the maximum heating value amongst the samples studied while the lowest carbon and highest oxygen content in the trunk biomass could be attributed to its lowest heating value among all the samples studied.

Table 2. Ultimate analysis and other related properties.

\begin{tabular}{|c|c|c|c|c|c|c|c|c|}
\hline $\begin{array}{l}\text { Biomass } \\
\text { Sample }\end{array}$ & $\mathrm{C}(\%)$ & H (\%) & N (\%) & $\mathrm{S}(\%)$ & $O *(\%)$ & $\mathrm{O} / \mathrm{C}$ & $\mathrm{H} / \mathrm{C}$ & $\begin{array}{c}\text { Empirical } \\
\text { Formula }\end{array}$ \\
\hline Phyllodes & $48.95 \pm 0.63$ & $6.01 \pm 0.14$ & $1.72 \pm 0.04$ & $0.20 \pm 0.01$ & $43.12 \pm 0.54$ & 0.66 & 1.47 & $\mathrm{CH}_{1.47} \mathrm{~N}_{0.12} \mathrm{O}_{0.66}$ \\
\hline Trunk & $45.50 \pm 0.59$ & $5.68 \pm 0.06$ & $0.49 \pm 0.01$ & $0.06 \pm 0.01$ & $48.27 \pm 0.34$ & 0.79 & 1.50 & $\mathrm{CH}_{1.50} \mathrm{~N}_{0.04} \mathrm{O}_{0.79}$ \\
\hline Bark & $47.74 \pm 0.27$ & $5.26 \pm 0.10$ & $0.94 \pm 0.02$ & $0.04 \pm 0.00$ & $43.11 \pm 0.24$ & 0.68 & 1.32 & $\mathrm{CH}_{1.32} \mathrm{~N}_{0.06} \mathrm{O}_{0.68}$ \\
\hline Twigs & $47.08 \pm 0.10$ & $5.44 \pm 0.07$ & $0.65 \pm 0.01$ & $0.01 \pm 0.00$ & $46.82 \pm 0.36$ & 0.75 & 1.39 & $\mathrm{CH}_{1.39} \mathrm{~N}_{0.04} \mathrm{O}_{0.75}$ \\
\hline Pods & $50.65 \pm 0.04$ & $5.36 \pm 0.01$ & $1.14 \pm 0.01$ & $0.16 \pm 0.01$ & $45.60 \pm 0.21$ & 0.68 & 1.27 & $\mathrm{CH}_{1.27} \mathrm{~N}_{0.08} \mathrm{O}_{0.68}$ \\
\hline Branches & $48.09 \pm 0.61$ & $5.66 \pm 0.03$ & $0.48 \pm 0.01$ & ND & $45.77 \pm 0.36$ & 0.71 & 1.41 & $\mathrm{CH}_{1.41} \mathrm{~N}_{0.03} \mathrm{O}_{0.71}$ \\
\hline
\end{tabular}

C: Carbon, H: Hydrogen, N: Nitrogen, S: Sulfur, O: Oxygen * Calculated by difference, ND = Not detected.

The nitrogen and sulfur content in the biomass feedstock is considered very important from the environmental emissions perspectives and the lower percentages of these elements are highly preferred. The nitrogen content was reported in the range of $0.48-1.72 \mathrm{wt} . \%$ with the highest and lowest values reported in phyllodes and branch biomass, respectively, 
while the sulfur content was also reported in a very low range of $0.01-0.2 \mathrm{wt} . \%$. The sulfur and nitrogen content in biomass can produce $\mathrm{SO}_{x}$ and $\mathrm{NO}_{x}$ in the biofuels, which cause severe environmental pollution and requires additional treatment procedures if the concentration of these elements exceeds the allowable limits. As per the World Health Organization (WHO) guidelines, the concentration of $\mathrm{SO}_{2}$ up to $500 \mu \mathrm{g} / \mathrm{m}^{3}$ should not be exceeded over the average period of 10 min exposure while for the $\mathrm{NO}_{2}$ at short-term, concentrations exceeding $200 \mu \mathrm{g} / \mathrm{m}^{3}$ can cause significant inflammation of the airways [50]. A comparatively higher percentage of nitrogen in the phyllodes than the biomass from other parts could be attributed to the nitrogen-fixing capabilities of these trees that allow them to thrive in deprived soil [51].

Figure 1 presents the Van-Krevelen diagram of the AM biomass samples used in this study along with the other solid fuels, including wood residues (rubber woods, white mulberry, and black wattle) $[52,53]$, torrefied camphorwood biomass blended with caster cake biomass at $300^{\circ} \mathrm{C}, 270{ }^{\circ} \mathrm{C}$, and $240{ }^{\circ} \mathrm{C}$ [54], coals of different origins [55], and pyrolyzed anthracite and untreated anthracite [55]. The $\mathrm{H} / \mathrm{C}$ and $\mathrm{O} / \mathrm{C}$ ratios help to identify the nature and biofuel potential of the fuels as a higher $\mathrm{H} / \mathrm{C}$ value indicates higher potential. In contrast, a higher $\mathrm{O} / \mathrm{C}$ value indicates a lower heating value and volatile content in biomass [56]. The ultimate analysis of the samples used in this study was in agreement with the results of different lignocellulosic biomass researched for bioenergy production via thermochemical routes $[19,29,38,57,58]$. The lower nitrogen and sulfur concentrations were very encouraging from an environmental pollution perspective.

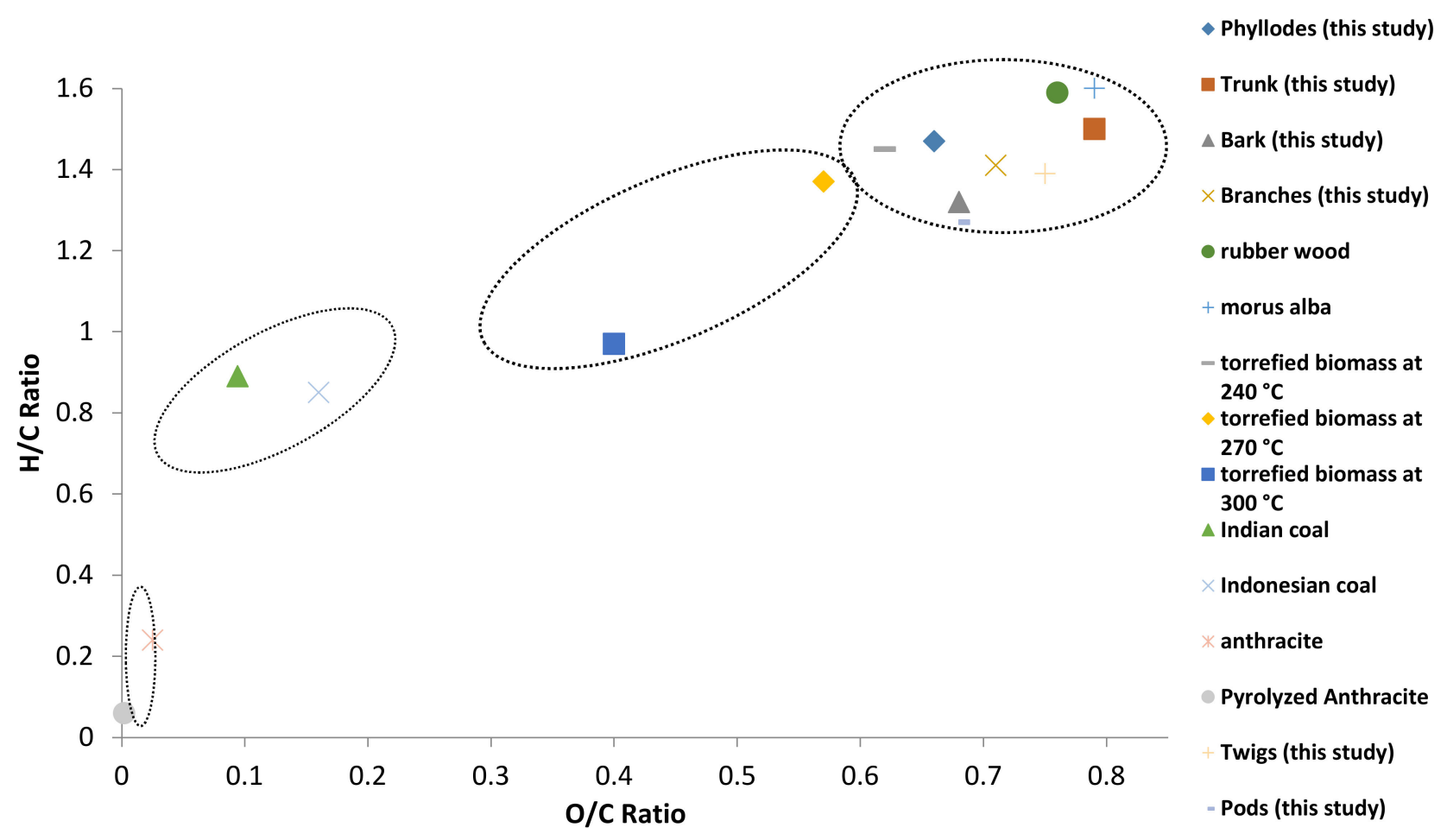

Figure 1. Van-Krevelen diagram of the biomass samples in this study with a comparison to other solid fuels.

\subsection{Heating Value (HHV) Analysis}

The HHV is a parameter for biomass selection that provides direct information about the energy value as a feedstock for pyrolysis and is defined as the total heat produced by the burning of a specific amount of biomass [59]. The HHV specifies the amount of energy content enclosed by specific biomass, and it is often termed as the calorific value. The $\mathrm{HHV}$ of the AM biomass samples was reported in the range of $19.51 \mathrm{MJ} / \mathrm{kg}-21.58 \mathrm{MJ} / \mathrm{kg}$ on a moisture dry basis. Among the biomass samples, the highest and lowest HHV was 
reported from the pods and trunk, respectively, which could be reasoned from the higher percentage of carbon and the lowest moisture content in the pods and vice versa. The biomass from twigs showed an HHV of $20.87 \mathrm{MJ} / \mathrm{Kg}$ regardless of the highest volatile matter content reported among the biomass samples used in this study. This reconfirmed that a higher percentage of volatile matter does not guarantee a higher HHV as discussed in the above section. This probably can be attributed to the high fractions of non-combustible components, such as $\mathrm{CO}_{2}$ and $\mathrm{H}_{2} \mathrm{O}$, in the volatile matter and the higher oxygen value.

The HHV of the AM biomass samples was higher than the HHV reported from Malaysian local tree species (Sentang and Sesendok), which had an HHV of $16.84 \mathrm{MJ} / \mathrm{kg}$ and $16.95 \mathrm{MJ} / \mathrm{Kg}$, respectively [60]. Moreover, the HHV reported in the present study were in good agreement with the forest biomass residues and woody biomass, including chips of the Chestnut tree, Eucalyptus bark, Cypress fruit biomass, Alder, and Hazelnut chips reported by García et al. [26], as well as oil palm, Euphorbia rigida, Sesame stalk, Acacia nilotica, A. auriculiformis, and palm kernel cake $[43,46,61,62]$. The difference in the HHV among the AM samples could be reasoned from the variation in the moisture content, carbon, hydrogen, and oxygen contents. Overall HHV analysis of the AM biomass samples highlighted its decent potential for energy conversion.

\subsection{Fourier Transform Infrared Analysis (FTIR)}

The FTIR spectra of the biomass samples from AM are shown in Figure 2 while Table 3 presents the analysis of the peaks attained from the FTIR spectra based on the literature $[18,20,29,63,64]$.

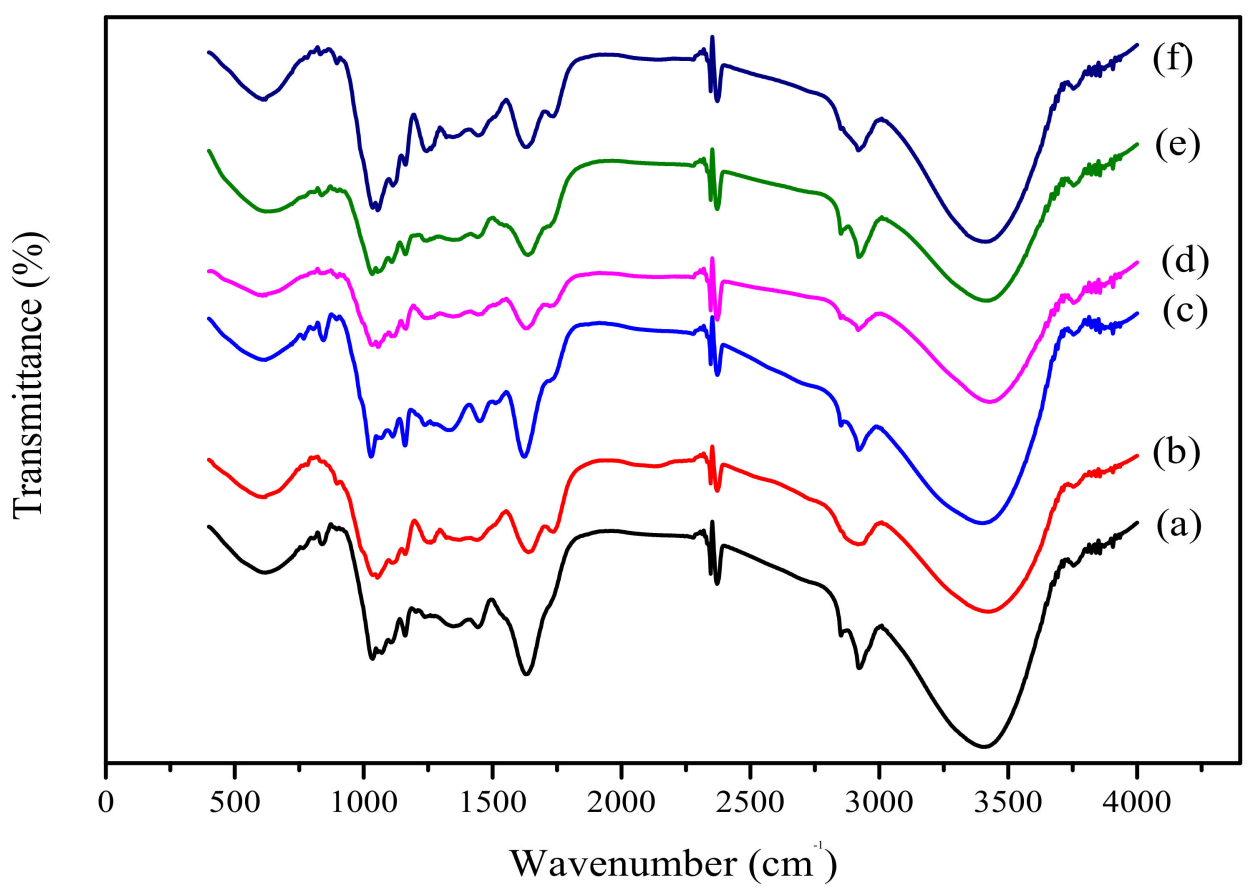

Figure 2. FTIR spectra of (a) phyllodes (b) trunk (c) bark (d) twig, (e) pod, and (f) branch biomass samples.

The heterogeneous nature of the AM biomass was confirmed by the identification of multiple functions present in the cellulose, hemicellulose, and lignin components of the samples. The functional groups including the O-H stretching in the Phenols, and alcohols (border peaks) were attained in the range of $3399-3423 \mathrm{~cm}^{-1}$, while the alkanes/primary amines or alkanes and acids or aliphatic $\mathrm{H}-\mathrm{C}-\mathrm{H}$ stretching peaks were attained in the range of 2914-2928 $\mathrm{cm}^{-1}$. The $\mathrm{C}=\mathrm{O}, \mathrm{C}=\mathrm{C}, \mathrm{H}-\mathrm{O}-\mathrm{H}$ stretching and deformation was observed in the trunk, twigs, and branch biomass while Aromatic $\mathrm{C}=\mathrm{C}$ ring stretching in all the samples was reported in the range of $1623-1638 \mathrm{~cm}^{-1}$. The aromatic $\mathrm{C}-\mathrm{C}$ stretching, 
deformation of $\mathrm{C}-\mathrm{H}$ was observed in all the $\mathrm{AM}$ samples except pod biomass in the range of $1438-1449 \mathrm{~cm}^{-1}$. The $\mathrm{C}-\mathrm{H}$ deformation in hemi-cellulose and cellulose was observed in the range of $1342-1373 \mathrm{~cm}^{-1}$ in all the samples. Aromatic C-O stretching was observed in the range of $1028-1072 \mathrm{~cm}^{-1}$ while the peaks in the range of $833-846 \mathrm{~cm}^{-1}$ were associated with the aromatic rings stretching and vibrations.

Table 3. Functional groups detected in the biomass samples by FTIR spectroscopy.

\begin{tabular}{ccccccc}
\hline Phyllodes & Trunk & Bark & Twigs & Pods & Branches & Functional Group \\
\hline 3403 & 3423 & 3399 & 3423 & 3404 & 3423 & Phenols, and alcohols (broader peaks) \\
\hline 2921 & 2914 & 2918 & 2914 & 2928 & 2918 & $\begin{array}{c}\text { Alkanes/primary amines or Alkanes and } \\
\text { acids / Aliphatic H-C-H stretching }\end{array}$ \\
\hline- & 1732 & - & 1728 & - & 1732 & C $=$ O, C $=\mathrm{C}, \mathrm{H}-\mathrm{O}-\mathrm{H}$ \\
\hline 1630 & 1638 & 1623 & 1628 & 1630 & 1637 & Aromatic C=C ring stretching \\
\hline 1441 & 1446 & 1449 & 1438 & - & 1441 & aromatic C-C stretching, Deformation of C-H \\
\hline 1349 & 1342 & 1353 & 1346 & 1373 & 1355 & C-H deformation in Hemicellulose and cellulose \\
\hline- & 1248 & - & - & - & 1246 & Esters or ethers \\
\hline 838 & 1053 & 1028 & 1056 & 1072 & 1059 & Aromatic C-O stretching \\
\hline
\end{tabular}

\subsection{Thermal Analysis (TGA and DTG Study)}

The thermal analysis is a commonly used technique to examine the pyrolytic characteristics of biomass feedstock and helps to understand the degradation behavior during thermochemical conversion processes. The degradation of biomass samples was studied in the temperature range of $50{ }^{\circ} \mathrm{C}$ to $900{ }^{\circ} \mathrm{C}$ at a heating rate of $25^{\circ} \mathrm{C} / \mathrm{min}$ using TGA. Figure 3 presents the pyrolytic curves (TGA and DTG) attained from the AM biomass samples. Several studies have described the examination of the degradation behavior of various feedstocks using the TGA technique $[65,66]$. The pyrolytic curves of the biomass from phyllodes and pods showed that the main decomposition took place between $150 \pm 10$ and $600 \pm 10^{\circ} \mathrm{C}$, while for the biomass from the trunk, bark, twigs, and branches it was reported in the range of $150 \pm 10$ and $500 \pm 10^{\circ} \mathrm{C}$. For all the biomass samples, decomposition was reported to be occurring in three major stages, covering the abstraction of moisture and light volatiles, main volatilization zone, and long-tailed slow decomposition of biomass. Table 4 lists the temperature ranges reported from the biomass decomposition of samples in this study. The first stage of weight loss from phyllodes, trunk, and pods biomass occurred between 50 and $140 \pm 10^{\circ} \mathrm{C}$, while it was between 50 and $100 \pm 10^{\circ} \mathrm{C}$ for bark, twigs, and branches biomass. The second stage, which was regarded as the main de-volatilization stage corresponding to the decomposition of hemicellulose and cellulose components for the trunk, bark, twigs, and branch biomass, was observed between $200 \pm 10{ }^{\circ} \mathrm{C}$ and $450 \pm 20^{\circ} \mathrm{C}$ while it was between $200 \pm 10{ }^{\circ} \mathrm{C}$ and $600 \pm 20^{\circ} \mathrm{C}$ for the phyllodes and pods biomass. During the major de-volatilization stage, the decomposition of most of the volatile matter in the biomass took place, which contributes in the yield of bio-oil during pyrolysis. Under this stage of disintegration, the temperature ranges of $220 \pm 20^{\circ} \mathrm{C}$ to $310 \pm 20^{\circ} \mathrm{C}$ and $315 \pm 20^{\circ} \mathrm{C}$ to $450 \pm 20^{\circ} \mathrm{C}$ were attributed to the hemicellulose and cellulose decomposition respectively for the trunk, bark, twigs, and branch biomass [67]. The biomass degradation resultant from the hemicellulose and cellulose components was found to be in good comparison with the temperature ranges reported for the different cellulosic biomasses from Canada, studied for energy potential [29]. 

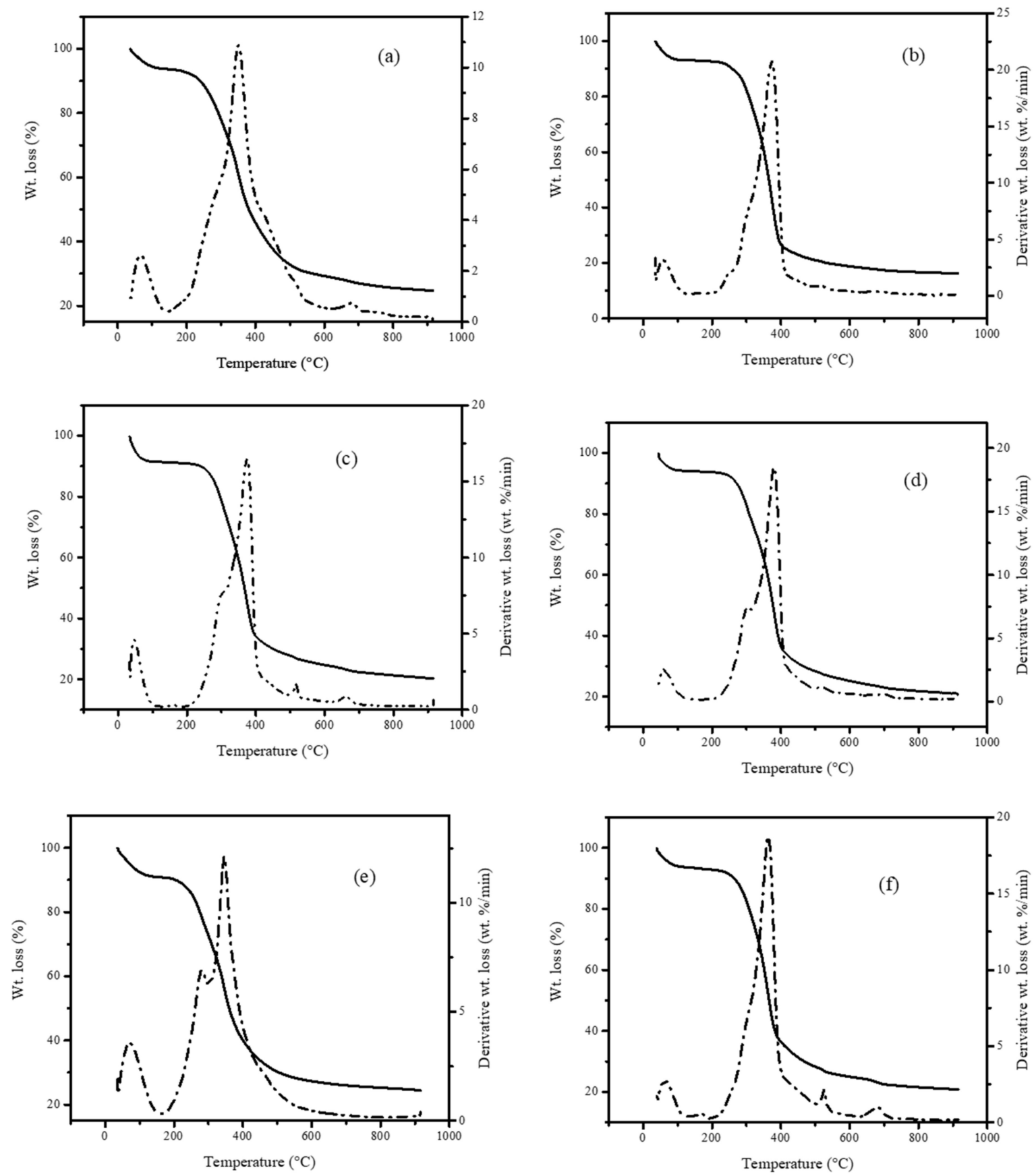

Figure 3. TGA and DTG curves of (a) phyllodes (b) trunk (c) bark (d) twigs, (e) pods, and (f) branch biomass under the pyrolytic degradation.

For the phyllodes and pods biomass, the temperature range between $220 \pm 20^{\circ} \mathrm{C}$ to $400 \pm 20^{\circ} \mathrm{C}$ was attributed to the hemicellulose decomposition, while the range $400 \pm 20$ to $600 \pm 20^{\circ} \mathrm{C}$ was attributed to the decomposition of cellulose components [67]. The weight loss from the main decomposition stage for all the samples was reported in the range 40 to $58 \mathrm{wt} . \%$ indicating a good potential for the production of bio-oil from the pyrolysis process and was also in good agreement with previously reported studies [68,69]. The lowest weight loss among all the samples was reported from the phyllodes biomass, which contained the highest fixed carbon content and high ash content, possibly resulted in the lower conversion of biomass to volatiles [40]. The prolonged main decomposition stage of phyllodes and pods biomass until a higher temperature up to $600 \pm 20^{\circ} \mathrm{C}$ indicated a comparatively lower prospective of these biomass samples to produce bio-oil compared 
to the other biomass samples from AM. Furthermore, comparatively larger energy inputs would be required for the conversion of phyllodes and pods biomass. The slight and lower variant slopes of the curves after decomposing the hemicellulose and cellulose constituents highlighted the slow and continual degradation of the lignin components up to $900{ }^{\circ} \mathrm{C}$. The phenomenon of dynamic disintegration of the main constituents of biomass during the pyrolytic conversion of biomass has been reported on [70,71]. Moreover, the pyrolytic degradation behavior of the AM biomass samples was comparable to the TGA and DTG analysis of other lignocellulosic biomasses studied for bioenergy production, including oil palm and pinewood biomass $[29,72]$.

Table 4. The temperature ranges reports during the pyrolytic degradation studies.

\begin{tabular}{cccc}
\hline Sample & 1st Stage $\left({ }^{\circ} \mathbf{C}\right)$ & 2nd Stage $\left({ }^{\circ} \mathbf{C}\right)$ & 3rd Stage $\left({ }^{\circ} \mathbf{C}\right)$ \\
\hline Phyllodes & 50 to $140 \pm 10$ & $200 \pm 10$ to $600 \pm 20$ & Up to 900 \\
\hline Trunk & 50 to $100 \pm 10$ & $200 \pm 10$ to $450 \pm 20$ & Up to 900 \\
\hline Bark & 50 to $100 \pm 10$ & $200 \pm 10$ to $450 \pm 20$ & Up to 900 \\
\hline Twigs & 50 to $100 \pm 10$ & $200 \pm 10$ to $450 \pm 20$ & Up to 900 \\
\hline Pods & 50 to $140 \pm 10$ & $200 \pm 10$ to $600 \pm 20$ & Up to 900 \\
\hline Branches & 50 to $100 \pm 10$ & $200 \pm 10$ to $450 \pm 20$ & Up to 900 \\
\hline
\end{tabular}

\section{Conclusions}

The pyrolytic conversion and thermochemical characteristics of the AM tree biomass in Brunei Darussalam were studied. The ash content, volatile matter, and moisture content in the samples were reported in the range of 1.41 to $2.69 \mathrm{wt} . \%, 69.82$ to $74.85 \mathrm{wt} . \%$, and 7.88 to $11.65 \mathrm{wt}$ \%, respectively. The ultimate analysis reported the carbon, hydrogen, and oxygen contents in the range of 45.50 to $50.65 \mathrm{wt} \%, 5.26$ to $6.01 \mathrm{wt} \%$, and 43.11 to 48.27 wt. \%, respectively. The heating values of the samples were reported to be $19.51 \mathrm{MJ} / \mathrm{kg}$ to $21.58 \mathrm{MJ} / \mathrm{kg}$. The FTIR analysis confirmed the heterogeneous nature of the biomass samples with the presence of multiple functional groups. The thermochemical properties of the samples stated the suitability as a biomass feedstock for the pyrolysis process to produce biofuels. The thermal analysis under pyrolytic conditions reported the peak decomposition of biomass in the ranges of $150 \pm 10$ to $500 \pm 10{ }^{\circ} \mathrm{C}$ for the trunk, bark twigs and branches biomass and $150 \pm 10$ to $600 \pm 10^{\circ} \mathrm{C}$ for the biomass from phyllodes and pods. The weight loss during the major biomass decomposition of the samples was reported in the range of 40 to $58 \mathrm{wt}$.\%. Based on the analyses results, the study established a better potential of trunk, bark, twigs, and branch biomass to produce higher yields of bio-oil as well as phyllodes and pods biomass to produce a higher yields of biochar.

Supplementary Materials: The following are available online at https:/ /www.mdpi.com/article/10 $.3390 /$ su13095249/s1, detailed procedures used for the proximate analysis, ultimate analysis, and heating value analysis.

Author Contributions: A.A. and M.S.A.B. developed the conceptualization and methodology of the study. R.S.S. and Y.-K.P. managed resources, provided supervision and valuable research insights into the study. A.R., S.H., and F.J. provided literature resources and helped in analysis. M.N.A. and N.S.S. contributed to the writing and provided valuable research insights. All authors have read and agreed to the published version of the manuscript.

Funding: The support from Brunei Research Council under the project (BRC/UBD/11) and the National Research Foundation of Korea under the projects (NRF-2020R1I1A1A01072793, NRF2020M1A2A2079801) is gratefully acknowledged.

Institutional Review Board Statement: Not applicable.

Informed Consent Statement: Not applicable.

Data Availability Statement: Data are provided within the article and Supplementary Data. 
Conflicts of Interest: The authors declare no conflict of interest.

\section{References}

1. Chowdhury, T.; Chowdhury, H.; Ahmed, A.; Park, Y. Energy, Exergy, and Sustainability Analyses of the Agricultural Sector in Bangladesh. Sustainability 2020, 12, 4447. [CrossRef]

2. Moogi, S.; Nakka, L.; Potharaju, S.S.P.; Ahmed, A.; Farooq, A.; Jung, S.C.; Rhee, G.H.; Park, Y.K. Copper promoted Co/MgO: A stable and efficient catalyst for glycerol steam reforming. Int. J. Hydrogen Energy 2020, 46, 18073-18084. [CrossRef]

3. Miskat, M.I.; Ahmed, A.; Rahman, M.S.; Chowdhury, H.; Chowdhury, T.; Chowdhury, P.M.; Sait, S.; Park, Y.-K. An Overview of the Hydropower Production Potential in Bangladesh to Meet the Energy Requirements. Environ. Eng. Res. 2020, 26, 120-132. [CrossRef]

4. Jamil, F.; Aslam, M.; Al-Muhtaseb, A.H.; Bokhari, A.; Rafiq, S.; Khan, Z.; Inayat, A.; Ahmed, A.; Hossain, S.; Khurrum, M.S.; et al. Greener and Sustainable Production of Bioethylene from Bioethanol: Current Status, Opportunities and Perspectives. Rev. Chem. Eng. 2020, 36. [CrossRef]

5. Ahmed, A.; Abu Bakar, M.S.; Sukri, R.S.; Hussain, M.; Farooq, A.; Moogi, S.; Park, Y.-K. Sawdust Pyrolysis from the Furniture Industry in an Auger Pyrolysis Reactor System for Biochar and Bio-Oil Production. Energy Convers. Manag. 2020, $42,113502$. [CrossRef]

6. Abdullah, A.; Ahmed, A.; Akhter, P.; Razzaq, A.; Hussain, M.; Hossain, N.; Abu Bakar, M.S.; Khurram, S.; Majeed, K.; Park, Y.K. Potential for Sustainable Utilisation of Agricultural Residues for Bioenergy Production in Pakistan: An Overview. J. Clean. Prod. 2020, 287, 125047. [CrossRef]

7. Abu Bakar, M.S.; Ahmed, A.; Jeffery, D.M.; Hidayat, S.; Sukri, R.S.; Mahlia, T.M.I.; Jamil, F.; Khurrum, M.S.; Inayat, A.; Moogi, S.; et al. Pyrolysis of Solid Waste Residues from Lemon Myrtle Essential Oils Extraction for Bio-Oil Production. Bioresour. Technol. 2020, 318, 123913. [CrossRef]

8. Radenahmad, N.; Morni, N.A.; Ahmed, A.; Abu Bakar, M.; Zaini, J.; Azad, A. Characterization of rice husk as a potential renewable energy source. In Proceedings of the 7th Brunei International Conference on Engineering and Technology (BICET 2018), Bandar Seri Begawan, Brunei, 12-14 November 2018; pp. 1-4. [CrossRef]

9. Hidayat, S.; Abu Bakar, M.S.; Ahmed, A.; Agustina, D.; Hussain, M.; Jamil, F.; Park, Y. Comprehensive Kinetic Study of Imperata Cylindrica Pyrolysis via Asym2sig Deconvolution and Combined Kinetics. J. Anal. Appl. Pyrolysis 2021, 156, 105133. [CrossRef]

10. Mahari, W.A.W.; Azwar, E.; Foong, S.Y.; Ahmed, A.; Peng, W.; Tabatabaei, M.; Aghbashlo, M.; Park, Y. Valorization of Municipal Wastes Using Co-Pyrolysis for Green Energy Production, Energy Security, and Environmental Sustainability: A Review. Chem. Eng. J. 2021, 421, 129749. [CrossRef]

11. Solarte-Toro, J.C.; González-Aguirre, J.A.; Poveda Giraldo, J.A.; Cardona Alzate, C.A. Thermochemical Processing of Woody Biomass: A Review Focused on Energy-Driven Applications and Catalytic Upgrading. Renew. Sustain. Energy Rev. 2021, 136, 110376. [CrossRef]

12. Rashidah, E.; Shazali, H.; Afiqah, N.; Morni, H.; Saifullah, M.; Bakar, A.; Ahmed, A.; Azad, A.K.; Phusunti, N.; Park, Y. Characterisation and Co-pyrolytic Degradation of the Sawdust and Waste Tyre Blends to Study the Effect of Temperature on the Yield of the Products. Appl. Chem. Eng. 2021, 32, 205-213.

13. Osunkoya, O.O.; Othman, F.E.; Kahar, R.S. Growth and Competition Between Seedlings of an Invasive Plantation Tree, Acacia Mangium, and those of a Native Borneo Heath-Forest Species, Melastoma Beccarianum. Ecol. Res. 2005, 20, 205-214. [CrossRef]

14. Ahmed, A.; Abu Bakar, M.S.; Azad, A.K.; Sukri, R.S.; Mahlia, T.M.I. Potential Thermochemical Conversion of Bioenergy from Acacia Species in Brunei Darussalam: A Review. Renew. Sustain. Energy Rev. 2017, 82, 3060-3076. [CrossRef]

15. Koutika, L.S.; Richardson, D.M. Acacia Mangium Willd: Benefits and Threats Associated with Its Increasing Use around the World. For. Ecosyst. 2019, 6, 2. [CrossRef]

16. Jambul, R.; Limin, A.; Ali, A.N.; Slik, F. Invasive Acacia Mangium Dominance as an Indicator for Heath Forest Disturbance. Environ. Sustain. Indic. 2020, 8, 100059. [CrossRef]

17. Matali, S.; Metali, F. Selected Soil Physico-Chemical Properties in the Acacia Mangium Plantation and the Adjacent Heath Forest at Andulau Forest Reserve. Malays. J. Soil Sci. 2015, 19, 45-48.

18. Akhtar, N.; Goyal, D.; Goyal, A. Physico-Chemical Characteristics of Leaf Litter Biomass to Delineate the Chemistries Involved in Biofuel Production. J. Taiwan Inst. Chem. Eng. 2015, 62, 239-246. [CrossRef]

19. Vassilev, S.; Baxter, D.; Andersen, L.; Vassileva, C. An Overview of the Chemical Composition of Biomass. Fuel 2010, 89, 913-933. [CrossRef]

20. Guimarães, J.L.; Frollini, E.; da Silva, C.G.; Wypych, F.; Satyanarayana, K.G. Characterization of Banana, Sugarcane Bagasse and Sponge Gourd Fibers of Brazil. Ind. Crop. Prod. 2009, 30, 407-415. [CrossRef]

21. Griffin, A.R.; Midgley, S.J.; Bush, D.; Cunningham, P.J.; Rinaudo, A.T. Global Uses of Australian Acacias-Recent Trends and Future Prospects. Divers. Distrib. 2011, 17, 837-847. [CrossRef]

22. Titiloye, J.O.; Abu Bakar, M.S.; Odetoye, T.E. Thermochemical Characterisation of Agricultural Wastes from West Africa. Ind. Crop. Prod. 2013, 47, 199-203. [CrossRef]

23. Pazmiño-Hernandez, M.; Moreira, C.M.; Pullammanappallil, P. Feasibility Assessment of Waste Banana Peduncle as Feedstock for Biofuel Production. Biofuels 2017, 7269, 1-12. [CrossRef] 
24. Singh, Y.D.; Mahanta, P.; Bora, U. Comprehensive Characterization of Lignocellulosic Biomass through Proximate, Ultimate and Compositional Analysis for Bioenergy Production. Renew. Energy 2017, 103, 490-500. [CrossRef]

25. Kan, T.; Strezov, V.; Evans, T.J. Lignocellulosic Biomass Pyrolysis: A Review of Product Properties and Effects of Pyrolysis Parameters. Renew. Sustain. Energy Rev. 2016, 57, 126-1140. [CrossRef]

26. García, R.; Pizarro, C.; Lavín, A.G.; Bueno, J.L. Spanish Biofuels Heating Value Estimation. Part I: Ultimate Analysis Data. Fuel 2014, 117, 1130-1138. [CrossRef]

27. Odetoye, T.E.; Onifade, K.R.; AbuBakar, M.S.; Titiloye, J.O. Thermochemical Characterisation of Parinari Polyandra Benth Fruit Shell. Ind. Crop. Prod. 2013, 44, 62-66. [CrossRef]

28. Abdullah, A.; Ahmed, A.; Akhter, P.; Razzaq, A.; Zafar, M.; Hussain, M.; Shahzad, N.; Majeed, K.; Khurrum, S.; Abu Bakar, M.S.; et al. Bioenergy Potential and Thermochemical Characterization of Lignocellulosic Biomass Residues Available in Pakistan. Korean J. Chem. Eng. 2020, 37, 1899-1906. [CrossRef]

29. Naik, S.; Goud, V.V.; Rout, P.K.; Jacobson, K.; Dalai, A.K. Characterization of Canadian Biomass for Alternative Renewable Biofuel. Renew. Energy 2010, 35, 1624-1631. [CrossRef]

30. Kumar, R.; Strezov, V.; Weldekidan, H.; He, J.; Singh, S.; Kan, T.; Dastjerdi, B. Lignocellulose Biomass Pyrolysis for Bio-Oil Production: A Review of Biomass Pre-Treatment Methods for Production of Drop-In Fuels. Renew. Sustain. Energy Rev. 2020, 123, 109763. [CrossRef]

31. Motta, I.L.; Miranda, N.T.; Filho, R.M.; Maciel, M.R.W. Biomass Gasification in Fluidized Beds: A Review of Biomass Moisture Content and Operating Pressure Effects. Renew. Sustain. Energy Rev. 2018, 94, 998-1023. [CrossRef]

32. Ahmed, A.; Abu Bakar, M.S.; Azad, A.K.; Sukri, R.S.; Phusunti, N. Intermediate Pyrolysis of Acacia Cincinnata and Acacia Holosericea Species for Bio-Oil and Biochar Production. Energy Convers. Manag. 2018, 176, 393-408. [CrossRef]

33. Din, Z.U.; Zainal, Z. Biomass Integrated Gasification-SOFC Systems: Technology Overview. Renew. Sustain. Energy Rev. 2016, 53, 1356-1376. [CrossRef]

34. Williams, C.L.; Westover, T.L.; Emerson, R.M.; Tumuluru, J.S.; Li, C. Sources of Biomass Feedstock Variability and the Potential Impact on Biofuels Production. Bioenergy Res. 2016, 9, 1-14. [CrossRef]

35. Kenney, K.L.; Smith, W.A.; Gresham, G.L.; Westover, T.L. Understanding Biomass Feedstock Variability. Biofuels 2013, 4, 111-127. [CrossRef]

36. Charusiri, W. Fast Pyrolysis of Residues from Paper Mill Industry to Bio-Oil and Value Chemicals: Optimization Studies. Energy Procedia 2015, 74, 933-941. [CrossRef]

37. Marsoem, S.N.; Irawati, D. Basic properties of Acacia mangium and Acacia auriculiformis as a heating fuel. AIP Conf. Proc. 2016, 1755, 130007. [CrossRef]

38. Garcia, R.; Pizarro, C.; Lavin, A.G.; Bueno, J.L. Characterization of Spanish Biomass Wastes for Energy Use. Bioresour. Technol. 2012, 103, 249-258. [CrossRef]

39. Kanwal, F.; Ahmed, A.; Jamil, F.; Rafiq, S.; Ayub, H.M.U.; Ghauri, M.; Khurram, M.S.; Munir, S.; Inayat, A.; Bakar, M.S.A.; et al. Co-Combustion of Blends of Coal and Underutilised Biomass Residues for Environmental Friendly Electrical Energy Production. Sustainability 2021, 13, 4881. [CrossRef]

40. Garcia, R.; Pizarro, C.; Lavin, A.G.; Bueno, J.L. Biomass Proximate Analysis Using Thermogravimetry. Bioresour. Technol. 2013, 139, 1-4. [CrossRef]

41. ÖzyuğUran, A.; Yaman, S. Prediction of Calorific Value of Biomass from Proximate Analysis. Energy Procedia 2017, 107, 130-136. [CrossRef]

42. Demiral, I.; Ayan, E.A. Pyrolysis of grape bagasse: Effect of pyrolysis conditions on the product yields and characterization of the liquid product. Bioresour. Technol. 2011, 102, 3946-3951. [CrossRef]

43. Kumar, R.; Pandey, K.K.; Chandrashekar, N.; Mohan, S. Study of age and height wise variability on calorific value and other fuel properties of Eucalyptus hybrid, Acacia auriculaeformis and Casuarina equisetifolia. Biomass Bioenergy 2011, 35, 1339-1344. [CrossRef]

44. Patwardhan, P.R.; Satrio, J.A.; Brown, R.C.; Shanks, B.H. Influence of inorganic salts on the primary pyrolysis products of cellulose. Bioresour. Technol. 2010, 101, 4646-4655. [CrossRef]

45. Liu, H.; Feng, Y.; Wu, S.; Liu, D. The role of ash particles in the bed agglomeration during the fluidized bed combustion of rice straw. Bioresour. Technol. 2009, 100, 6505-6513. [CrossRef]

46. Garg, R.; Anand, N.; Kumar, D. Pyrolysis of babool seeds (Acacia nilotica) in a fixed bed reactor and bio-oil characterization. Renew. Energy 2016, 96, 167-171. [CrossRef]

47. Lacey, J.A.; Aston, J.E.; Thompson, V.S. Wear properties of ash minerals in biomass. Front. Energy Res. 2018, 6, 119. [CrossRef]

48. Liu, W.J.; Li, W.W.; Jiang, H.; Yu, H.Q. Fates of Chemical Elements in Biomass during Its Pyrolysis. Chem. Rev. 2017, 117, 6367-6398. [CrossRef]

49. Obernberger, I.; Brunner, T.; Barnthaler, G. Chemical properties of solid biofuels-significance and impact. Biomass Bioenergy 2006, 30, 973-982. [CrossRef]

50. World Health Organization. Ambient (Outdoor) Air Pollution Standards. Available online: https://www.who.int/news-room/ fact-sheets/detail/ambient-(outdoor)-air-quality-and-health (accessed on 23 April 2021).

51. Galiana, A.; Chaumont, J.; Diem, H.G.; Dommergues, Y.R. Nitrogen-Fixing Potential of Acacia Mangium and Acacia Auriculiformis Seedlings Inoculated with Bradyrhizobium and Rhizobium spp. Biol. Fertil. Soils 1990, 9, 261-267. [CrossRef] 
52. Abe, H.; Katayama, A.; Sah, B.P.; Toriu, T.; Samy, S.; Pheach, P.; Adams, M.A.; Grierson, P.F. Potential for Rural Electrification Based on Biomass Gasification in Cambodia. Biomass Bioenergy 2007, 31, 656-664. [CrossRef]

53. Crespo, Y.A.; Naranjo, R.A.; Quitana, Y.G.; Sanchez, C.G.; Sanchez, E.M.S. Optimisation and Characterisation of Bio-Oil Produced by Acacia Mangium Willd Wood Pyrolysis. Wood Sci. Technol. 2017, 51, 1155-1171. [CrossRef]

54. Cao, L.; Yuan, X.; Jiang, L.; Li, C.; Xiao, Z.; Huang, Z.; Chen, X.; Zeng, G.; Li, H. Thermogravimetric Characteristics and Kinetics Analysis of Oil Cake and Torrefied Biomass Blends. Fuel 2016, 175, 129-136. [CrossRef]

55. Lyubchik, S.B.; Benoit, R.; Béguin, F. Influence of Chemical Modification of Anthracite on the Porosity of the Resulting Activated Carbons. Carbon N.Y. 2002, 40, 1287-1294. [CrossRef]

56. Nhuchhen, D.R.; Afzal, M.T. HHV predicting correlations for torrefied biomass using proximate and ultimate analyses. Bioengineering 2017, 4, 7. [CrossRef]

57. Salaheldeen, M.; Aroua, M.K.; Mariod, A.A.; Cheng, S.F.; Abdelrahman, M.A. An Evaluation of Moringa Peregrina Seeds as a Source for Bio-Fuel. Ind. Crop. Prod. 2014, 61, 49-61. [CrossRef]

58. Sasmal, S.; Goud, V.V.; Mohanty, K. Characterization of Biomasses Available in the Region of North-East India for Production of Biofuels. Biomass Bioenergy 2012, 45, 212-220. [CrossRef]

59. Boumanchar, I.; Charafeddine, K.; Chhiti, Y.; Alaoui, F.E.M.; Sahibed-dine, A.; Bentiss, F.; Jama, C.; Bensitel, M. Biomass Higher Heating Value Prediction from Ultimate Analysis Using Multiple Regression and Genetic Programming. Biomass Convers. Biorefinery 2019, 9, 499-509. [CrossRef]

60. Hossain, N.; Rafidah, J. Analysis of Bio-Energy Properties from Malaysian Local Plants: Sentang and Sesendok. Asia Pac. J. Energy Environ. 2015, 2, 141-144.

61. Ahmed, A.; Hidayat, S.; Abu Bakar, M.S.; Azad, A.K.; Sukri, R.S.; Phusunti, N. Thermochemical Characterisation of Acacia Auriculiformis Tree Parts via Proximate, Ultimate, TGA, DTG, Calorific Value and FTIR Spectroscopy Analyses to Evaluate their Potential as a Biofuel Resource. Biofuels 2018, 7269, 1-12. [CrossRef]

62. Weerachanchai, P.; Tangsathitkulchai, C.; Tangsathitkulchai, M. Characterization of Products from Slow Pyrolysis of Palm Kernel Cake and Cassava Pulp Residue. Korean J. Chem. Eng. 2011, 28, 2262-2274. [CrossRef]

63. Mothé, C.G.; De Miranda, I.C. Characterization of Sugarcane and Coconut Fibers by Thermal Analysis and FTIR. J. Therm. Anal Calorim. 2009, 97, 661-665. [CrossRef]

64. Özçimen, D.; Ersoy-Meriçboyu, A. Characterization of Biochar and Bio-Oil Samples Obtained from Carbonization of Various Biomass Materials. Renew. Energy 2010, 35, 1319-1324. [CrossRef]

65. Slopiecka, K.; Bartocci, P.; Fantozzi, F. Thermogravimetric Analysis and Kinetic Study of Poplar Wood Pyrolysis. Appl. Energy 2012, 97, 491-497. [CrossRef]

66. Mishra, R.K.; Mohanty, K. Pyrolysis Kinetics and Thermal Behavior of Waste Sawdust Biomass Using Thermogravimetric Analysis. Bioresour. Technol. 2018, 251, 63-74. [CrossRef]

67. Munir, S.; Daood, S.S.; Nimmo, W.; Cunliffe, A.M.; Gibbs, B.M. Thermal Analysis and Devolatilization Kinetics of Cotton Stalk, Sugar Cane Bagasse and Shea Meal Under Nitrogen and Air Atmospheres. Bioresour. Technol. 2009, 100, 1413-1418. [CrossRef]

68. Márquez-Montesino, F.; Correa-Méndez, F.; Glauco-Sánchez, G.; Zanzi-Vigouroux, R.; Rutiaga-Quiñones, J.; Aguiar-Trujillo, L. Pyrolytic Degradation Studies of Acacia Mangium Wood. BioResources 2015, 10, 1825-1844. [CrossRef]

69. Mehmood, M.A.; Ye, G.; Luo, H.; Liu, C.; Malik, S.; Afzal, I.; Xu, J.; Ahmad, M.S. Pyrolysis and Kinetic Analyses of Camel Grass (Cymbopogon Schoenanthus) for Bioenergy. Bioresour. Technol. 2017, 228, 18-24. [CrossRef]

70. Manyá, J.J.; Velo, E.; Puigjaner, L. Kinetics of Biomass Pyrolysis: A Reformulated Three-Parallel-Reactions Model. Ind. Eng. Chem. Res. 2003, 42, 434-441. [CrossRef]

71. Yang, H.; Yan, R.; Chen, H.; Zheng, C.; Lee, D. In-depth Investigation of Biomass Pyrolysis Based on Three Major Components: Hemicellulose, Cellulose and Lignin. Energy Fuels 2006, 20, 388-393. [CrossRef]

72. Park, Y.H.; Kim, J.; Kim, S.S.; Park, Y.K. Pyrolysis Characteristics and Kinetics of Oak Trees Using Thermogravimetric Analyzer and Micro-Tubing Reactor. Bioresour. Technol. 2009, 100, 400-405. [CrossRef] 